\title{
RESPONSES OF LEAF PROCESSING TO IMPACTS IN STREAMS IN ATLANTIC RAIN FOREST, RIO DE JANEIRO, BRAZIL - A TEST OF THE BIODIVERSITY-ECOSYSTEM FUNCTIONING RELATIONSHIP?
}

\author{
MOULTON, T. P. ${ }^{1}$ and MAGALHÃES, S. A. P. ${ }^{1}$ \\ ${ }^{1}$ Departamento de Ecologia, IBRAG, Universidade do Estado do Rio de Janeiro, RJ, Brazil \\ Correspondence to: Timothy P. Moulton, Departamento de Ecologia, IBRAG, Universidade do Estado do \\ Rio de Janeiro, Rua São Francisco Xavier, 524, Rio de Janeiro, CEP 20550-011, RJ, Brazil, \\ e-mail: bragamoulton@alternex.com.br or moulton@uerj.br \\ Received October 24, 2001 - Accepted February 21, 2002 - Distributed February 28, 2003
}

(With 4 figures)

\begin{abstract}
The relationship between biodiversity and ecosystem functioning has been intensely debated and researched in recent times. It is generally agreed that there is redundancy of species in ecosystems such that loss of species does not necessarily result in change in the functioning of the ecosystem in which they occur. However the state of our knowledge does not allow prediction of sensitivity or specificity of this relationship for any particular ecosystem. A widely-held opinion is that ecosystem functioning is relatively stable to environmental impact, whereas biodiversity is more sensitive. We tested this in streams of the Atlantic forest using leaf decomposition as an aspect of ecosystem functioning and measuring the diversity of the associated fauna. In lightly impacted streams of the urban park Parque Estadual da Pedra Branca, RJ, leaf processing rate of a hard-leaf species, Myrcia rostrata (Myrtaceae) was more than 50\% slower than in "intact" streams at the biological reserve of Ilha Grande, RJ. Taxon diversity of fauna of the leaves was not significantly lower in the impacted than the intact streams. We construe this as preliminary evidence contrary to the notion that ecosystem functioning is less sensitive than biodiversity to impacts in this system.
\end{abstract}

Key words: ecosystem functioning, biodiversity, environmental impact, urban impact, stream, Atlantic rain forest, decomposition, leaf processing, macroinvertebrates.

\section{RESUMO}

Respostas do processamento de folha a impactos em córregos de Mata Atlântica, Rio de Janeiro, Brasil - uma prova da relação entre biodiversidade e funcionamento de ecossistema?

A relação entre biodiversidade e funcionamento de ecossistema tem sido debatida e pesquisada intensivamente em tempos recentes. Concorda-se geralmente que existe redundância de espécies em ecossistemas que faz com que a perda de espécies não necessariamente implique mudança no funcionamento do ecossistema em que ocorrem. Porém, o estado de nosso conhecimento não permite previsão de sensibilidade ou especificidade dessa relação para qualquer ecossistema. Uma opinião amplamente aceita é que o funcionamento do ecossistema fica relativamente estável ao impacto ambiental; em contrapartida, a biodiversidade é mais sensível. Testamos isto em córregos da Mata Atlântica usando decomposição de folha como aspecto de funcionamento de ecossistema e medindo a diversidade da fauna associada. Em rios levemente impactados do parque urbano Parque Estadual da Pedra Branca, RJ, o processamento de folhas de uma espécie com folhas duras, Myrcia rostrata (Myrtaceae), foi mais que 50\% mais lento se comparado com córregos "intactos" da reserva biológica da Ilha Grande, RJ. Diversidade de táxons da fauna das folhas não foi estatisticamente diferente entre 
os córregos. Consideramos isto como evidência preliminar contrária à noção de que funcionamento de ecossistema é menos sensível do que a biodiversidade nesse sistema.

Palavras-chave: funcionamento de ecossistema, biodiversidade, impacto ambiental, impacto urbano, córrego, Mata Atlântica, decomposição, processamento de folhas, macroinvertebrados.

\section{INTRODUCTION}

The relationship between biodiversity and ecosystem functioning is fundamental to Ecology and important in the context of Conservation. It has been known or at least suspected for many years that ecosystems contain a redundancy of species, and that all species are not necessary for continuing functioning of the ecosystem. The question gained prominence in the 1980s when Ehrlich \& Ehrlich (1981) published their nowfamous "rivets" analogy: all of the rivets of a plane's wing are not necessary for the plane to keep flying, and one could imagine that the loss of a few would not be noticed. However, at some particular level of loss of rivets the wing of the plane will fall off and the plane will crash. Ecosystems possibly behave in an analogous fashion, with little perceptible change as the first species are lost, but catastrophic change at a certain degree of species loss. Research in the intervening years has generally validated the existence of redundancy, but has not uncovered any quantitative relationship between the number of species and the functioning of the various components of the ecosystem. The question is difficult to analyze in natural and impacted systems, because species loss is generally not independent of impact, and the observed changes cannot be attributed to species loss per se. The problem has generally been tackled by large experimental programs in which communities of different numbers of species are constructed and the ecosystem parameters measured (Hector et al., 1999). There is some evidence of the importance of species diversity in maintaining the stability of production (Maltchik \& Pedro, 2000; Tilman \& Downing, 1994).

A relationship between species diversity and environmental impact is implicit in the now almost universal practice of using natural communities for monitoring. It is presumed that observed reductions in species number, diversity and composition are the consequence of environmental impact (Moulton, 1998; Rosenberg \& Resh, 1993). Just how this relates to the functioning of the impacted study area is not always clear. However, the sensitivity of the relationship has been shown to be high in many systems. Moreover, the orthodoxy appears to be that species' reactions are much more sensitive to impact than are ecosystem processes. Reice \& Wohlenberg are quite explicit on this point: "[Likewise,] primary and secondary productivity are amazingly stable under all but the most extreme conditions of environmental deterioration. In contrast, benthic macroinvertebrate populations and the benthic community display far greater sensitivity to several types of disturbance" (Reice \& Wohlenber, 1993).

We began a program to test this hypothesis in the tropical stream environment, using leaf decomposition as an ecosystem function and measuring the diversity of the fauna associated. We reasoned that even if leaf decomposition proved to be not as sensitive to environmental perturbation as biodiversity, it is still a basic part of the system and probably interesting and important to characterize. As well, the methodology allows simultaneous investigation of both function and diversity and is thus possibly a powerful monitoring tool.

\section{METHODS}

\section{Study area}

We studied the loss of mass of leaves and the fauna associated in second and third order streams of coastal forest ("Atlantic rain forest") in Rio de Janeiro state, Brazil. Study sites were located in an urban park of Rio de Janeiro city, "Parque Estadual da Pedra Branca" (area 12,400 ha) and at Ilha Grande, an intact reserve in the south of the state (area 19,000 ha). The urban streams have relatively intact forest cover and are impacted by direct human disturbance, urban atmospheric pollution, heavy urban impact downstream but no waste disposal and little habitation upstream of the study. 
We carried out experiments in two urban "impacted" streams. One stream, Rio Grande, was catastrophically affected by heavy rains in February 1996, which completely modified the stream bed and removed forest from a strip approximately 10 $m$ of each bank. The stream was quite open to sunlight and we code it "impacted-open". The other stream, Rio da Padaria, which is a tributary of Rio Grande, was not greatly modified by the rain event and had normal, heavy, shading and we term it "impacted-closed". The two "intact" streams, Rio Andorinha and Rio Barra Pequena, were shaded by dense forest.

\section{Leaf processing}

We selected two plant species Myrcia rostrata (Myrtaceae), an understorey tree with relatively hard leaves and Piper divaricatum (Piperaceae), an herbaceous shrub with relatively soft leaves. We constructed packs of 5 leaves (Piper) (mean $3.00 \mathrm{~g}$, range 1.96 to $4.86 \mathrm{~g}$ ) or 10 leaves (Myrcia) (mean $0.34 \mathrm{~g}$, range 0.27 to $0.41 \mathrm{~g}$ ), attached them to dressmaker's elastic by plastic ties and destructively sampled at regular intervals of immersion $(2,4,8,16$ and 32 days in the impacted streams and 2, 8, 14, 20, 26 and 32 days in the intact streams). We measured the mass of the leaf pack before and after immersion. In the impacted streams we used fresh leaves; in the intact streams we dried the leaves before immersion. In both cases, we dried the leaves to constant mass at $50^{\circ} \mathrm{C}$ after retrieving them and before weighing. We corrected the mass of the fresh leaves in the impacted streams to the expected dry mass, after establishing the relationship between fresh and dry mass for the 2 species. We set out 2 series of each leaf species at each of 3 sites in both impacted streams and 6 sites in both intact streams. The impacted sites were studied in October-November 1996, and the intact sites in January-February 1997; a complete account of the method and the design of the experiments in the intact streams are found in Magalhães (1998).

\section{Fauna}

At the time of removal of the leaf packs from the stream we placed them in $80 \%$ ethanol to preserve the associated fauna (macroinvertebrates). In the laboratory we separated and counted the fauna. Faunal identification was to morpho-species within families for Ephemeroptera, families of
Trichoptera, Coleoptera, Diptera and Odonata, orders of Acari and Crustacea, apart from decapod crustaceans for which the species were known. We also observed the larger fauna (fish, crustaceans and tadpoles) present in the streams.

\section{Statistical analysis}

The rate of leaf processing was calculated from the linear regression of the natural $\log$ of the proportion of the remaining mass against the time of immersion (Benfield, 1996; Gessner, 1991; Gessner \& Chauvet, 1994). This analysis implies that the initial interval is discounted; it often represents a "leaching" phase of more rapid mass loss. The rate of mass loss in the subsequent intervals is assumed constant, conforming to the equation:

$$
\begin{gathered}
M_{t}=M_{0} e^{k t} \\
\log _{e}\left(\frac{M_{t}}{M_{0}}\right)=k t
\end{gathered}
$$

where $M_{t}$ and $M_{0}$ are the leaf mass at times 0 and $t$ (days), $e$ is the base of Napierian logarithms and $k$ is the instantaneous rate of leaf mass loss per day.

We compared processing rate between streams by pooling all data of each stream (proportion of remaining mass) and calculating a single $k$, with associated standard error. Significant differences between slopes were detected in a General Linear Model as interactions between the fixed factor (stream) and time of immersion, using the statistical program SYSTAT. Differences between intact and impacted streams were detected by nested ANOVA of $k$ values of each sample point of each stream nested within treatment (intact or impacted), using SYSTAT. Taxon diversity was compared between streams as total richness of combined leaf packs per stream, taxon richness per leaf pack and Simpson's diversity index per leaf pack.

\section{RESULTS}

Leaf processing rate of Myrcia was slower in impacted streams compared to intact streams (Fig. 1, Table 1). Mass loss did not follow a simple exponential relationship; the natural logarithm of the proportion of leaf mass remaining was not linear in time, but variously "humped" in the different streams. 
TABLE 1

Processing rate of two leaf species in "intact" and "impacted" streams.

\begin{tabular}{|c|c|c|c|c|c|c|c|c|}
\hline & \multicolumn{2}{|c|}{ Intact-1 } & \multicolumn{2}{|c|}{ Intact-2 } & \multicolumn{2}{|c|}{ Impacted-open } & \multicolumn{2}{|c|}{ Impacted-closed } \\
\hline & rate & $\pm^{1}$ & rate & \pm & rate & \pm & Rate & \pm \\
\hline \multicolumn{9}{|c|}{ Myrcia rostrata } \\
\hline$k\left(\right.$ day $\left.^{-1}\right)$ & -0.042 & 0.011 & -0.042 & 0.013 & -0.019 & 0.0044 & -0.017 & 0.0049 \\
\hline \multicolumn{9}{|c|}{ Piper divaricatum } \\
\hline $\begin{array}{l}k\left(\text { day }^{-1}\right) \\
(\text { day } 2-8)^{2}\end{array}$ & -0.249 & 0.099 & -0.141 & 0.088 & $\mathrm{~ns}^{3}$ & - & ns & - \\
\hline $\begin{array}{l}k\left(\text { day }^{-1}\right) \\
(\text { day } 8-16)^{2}\end{array}$ & -0.182 & 0.143 & -0.164 & 0.123 & -0.191 & 0.121 & -0.262 & 0.154 \\
\hline
\end{tabular}

$1.95 \%$ confidence interval about mean.

2. Interval for which $k$ was calculated.

3. Not statistically significantly different from zero.

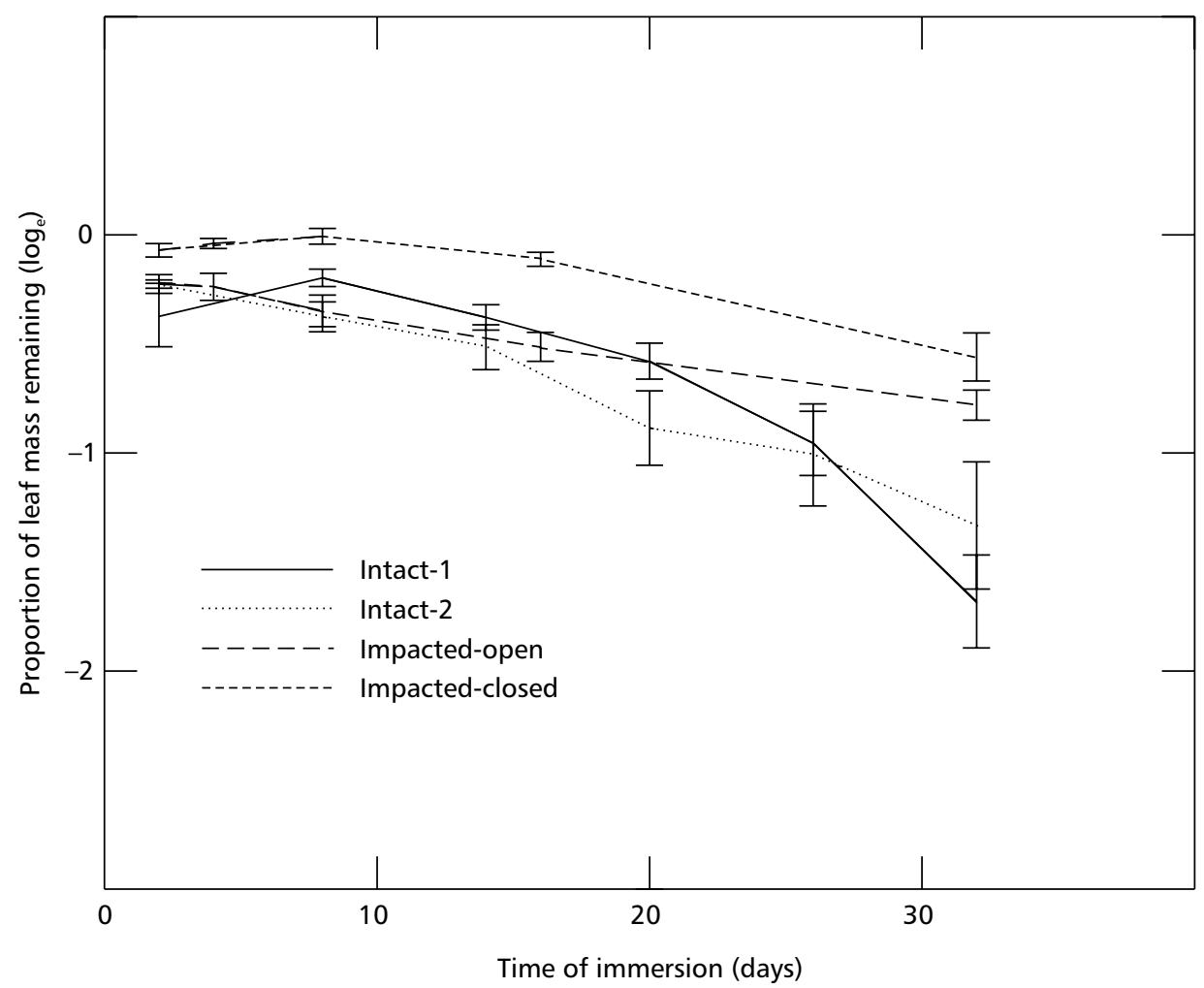

Fig. 1 - Rate of processing of Myrcia rostrata leaf packs in impacted and intact streams. Bars represent the standard error of the mean ( $n=12$ for intact streams, $n=6$ for impacted streams). $\log _{e}(-1)$ corresponds to $37 \%$ of original leaf mass. 
This made the calculation of an overall processing rate less precise, but we present it for comparison of the streams and with the literature (Table 1); the rate of leaf processing was significantly greater in the intact streams compared to impacted ( $\mathrm{p}<0.01$, ANOVA of streams nested within impactedness). The mass of leaves remaining at the end of the experiments (after 32 days) was $28 \%$ of the original in intact streams, $45 \%$ in impacted-open and $61 \%$ in impactedclosed.

Leaf processing was much faster in the softleaved Piper, and no measurable mass remained after 26 and 32 days in each experiment. The breakdown curves were different in the two treatments, and it is difficult to interpret the result. The loss of mass during the first 2 days ("leaching phase") was similar in the 4 streams. From day 2 to day 8 after immersion, Piper leaves in the impacted stream appeared not to decompose, whereas the leaves in intact streams lost mass rapidly $\left(k=-0.25\right.$ and -0.14 day $^{-1}$, Fig. 2 , Table $1)$. Thereafter, leaves in both treatments lost mass rapidly and not significantly differently between the 4 streams. Several authors have commented on differences in form of decay between fresh and dried material, and Bärlocher (1997) reviewed the problems that could be incurred. Based on the experiments of Gessner (1991) we would have expected to see a faster rate in the first 2 days ("leaching phase") in the dried leaves of the intact streams compared to the fresh leaves of the impacted streams, but not necessarily a continuing difference between fresh and dry leaves during the subsequent 6 days.

The fauna associated with leaf packs was not significantly less diverse in the impacted streams, both in terms of richness and Simpson's diversity index (Table 2). We did not process all leaf packs for fauna, but the rate of accumulation of new taxa had stopped well before the last-processed sample of each stream.

The fauna showed marked differences between impacted and intact streams, and some differences associated with leaf species (Fig. 3). Simulid larvae (Diptera) were found only in impacted streams and chironomid larvae (Diptera) were more abundant in impacted streams. Ephemeropteran larvae showed mixed responses: leptophlebiids were significantly more abundant on Myrcia in intact streams, but not on Piper; baetids were not significantly different between intact and impacted streams. Trichoptera were not abundant and showed sporadic occurrence. Other taxa, such as Plecoptera, Elmidae (Coleoptera) and Ceratopogonidae (Dipera) were encountered on leaf packs, but were too rare to analyse.

\section{DISCUSSION}

Leaf processing rate was less in impacted streams. The hard-leaf species, Myrcia, demonstrated this relationship clearly; the soft-leaf species, Piper, decomposed rapidly and appeared to be affected by mechanical breakdown which may have obscured differences between streams (Figs. 2 and 3).

Diversity of macroinvertebrates associated with the decomposing leaves was not significantly less in impacted streams at the level of taxonomic differentiation we used (Table 2). We construe this as preliminary evidence counter to the hypothesis (Reice \& Wohlenberg, 1993) that biodiversity is more sensitive to impact than is functioning; the opposite appears to be the case in this study. The data are not conclusive because we cannot eliminate the possibility that the streams were inherently different before impact. We note that the "impacted" streams at Parque Estadual da Pedra Branca issue from relatively intact forest, which has negligible present human habitation and no direct input of pollution. We would subjectively place these streams at the less-impacted end of the spectrum of impactedness. The downstream part of these streams is heavily impacted by sewerage, and possibly this has an effect on ecosystem functioning upstream. In particular, the species that need downstream parts of the streams for their life cycle, such as amphidromous shrimp and fish, are eliminated from the impacted streams. This phenomenon has been characterized as "disturbance going against the flow", and shown to be important in streams of Puerto Rico (Pringle, 1997).

We also cannot determine from the experiment the causal mechanism of the observed differences. Assuming that the decline in processing rate was associated with impact and not intrinsic differences between streams, we would like to know if impact negatively affected some component of the fauna which in turn reduced the leaf processing rate. Or alternatively if the impact affected leaf processing directly, Fig. 4. 
TABLE 2

Diversity of fauna associated with leaf packs in 2 "intact" and 2 "impacted" streams.

\begin{tabular}{|l|c|c|c|c|c|c|c|c|}
\hline & \multicolumn{2}{|c|}{ Intact-1 } & \multicolumn{2}{c|}{ Intact-2 } & \multicolumn{2}{c|}{ Impacted-open } & \multicolumn{2}{c|}{ Impacted-closed } \\
\hline & Myrcia & Piper & Myrcia & Piper & Myrcia & Piper & Myrcia & Piper \\
\hline $\begin{array}{l}\text { Total taxon richness } \\
\text { (n. leaf packs) }\end{array}$ & $\begin{array}{c}4 \\
(22)\end{array}$ & $\begin{array}{c}7 \\
(17)\end{array}$ & $\begin{array}{c}4 \\
(14)\end{array}$ & $\begin{array}{c}6 \\
(13)\end{array}$ & $\begin{array}{c}5 \\
(19)\end{array}$ & $\begin{array}{c}5 \\
(16)\end{array}$ & $\begin{array}{c}5 \\
(7)\end{array}$ & $\begin{array}{c}4 \\
(12)\end{array}$ \\
\hline $\begin{array}{l}\text { Taxon richness per leaf pack } \\
\text { (s.e.) }\end{array}$ & $\begin{array}{c}2.27 \\
(0.36)\end{array}$ & $\begin{array}{c}3.12 \\
(0.31)\end{array}$ & $\begin{array}{c}1.79 \\
(0.35)\end{array}$ & $\begin{array}{c}2.77 \\
(0.34)\end{array}$ & $\begin{array}{c}3.21 \\
(0.27)\end{array}$ & $\begin{array}{c}2.87 \\
(0.24)\end{array}$ & $\begin{array}{c}2.57 \\
(0.43)\end{array}$ & $\begin{array}{c}3.50 \\
(0.40)\end{array}$ \\
\hline $\begin{array}{l}\text { Simpson's diversity per leaf pack } \\
\text { (s.e.) }\end{array}$ & $\begin{array}{c}0.30 \\
(0.064)\end{array}$ & $\begin{array}{c}0.33 \\
(0.049)\end{array}$ & $\begin{array}{c}0.22 \\
(0.067)\end{array}$ & $\begin{array}{c}0.31 \\
(0.066)\end{array}$ & $\begin{array}{c}0.28 \\
(0.027)\end{array}$ & $\begin{array}{c}0.23 \\
(0.037)\end{array}$ & $\begin{array}{c}0.16 \\
(0.047)\end{array}$ & $\begin{array}{c}0.22 \\
(0.045)\end{array}$ \\
\hline
\end{tabular}

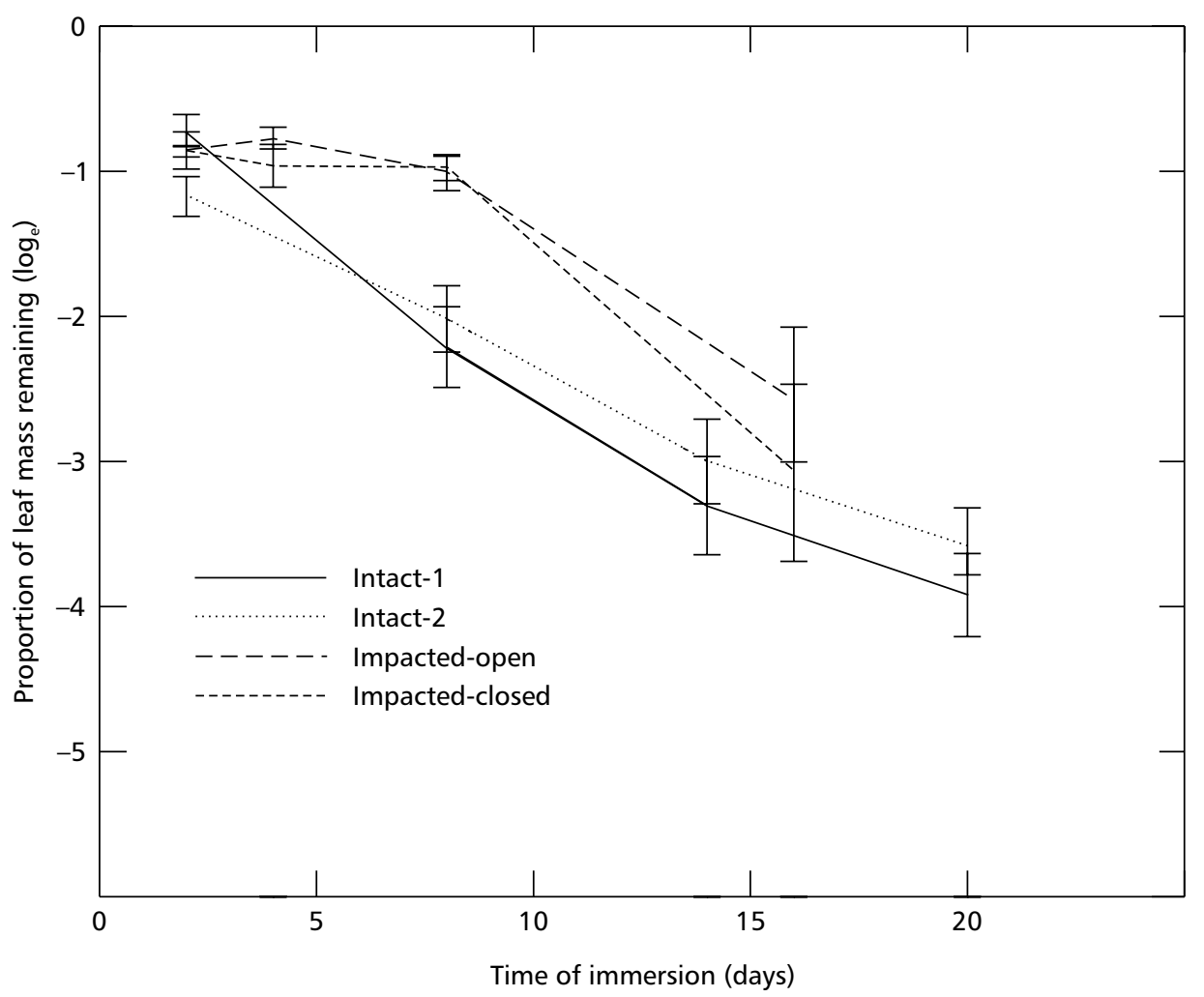

Fig. 2 - Rate of processing of Piper rostrata leaf packs in impacted and intact streams. Bars represent the standard error of the mean ( $\mathrm{n}=12$ for intact streams, $\mathrm{n}=6$ for impacted streams). Most of the material had been processed by day 26 and 32 and data for these days are not shown. $\log _{\mathrm{e}}(-3)$ corresponds to $5 \%$ of original leaf mass. 

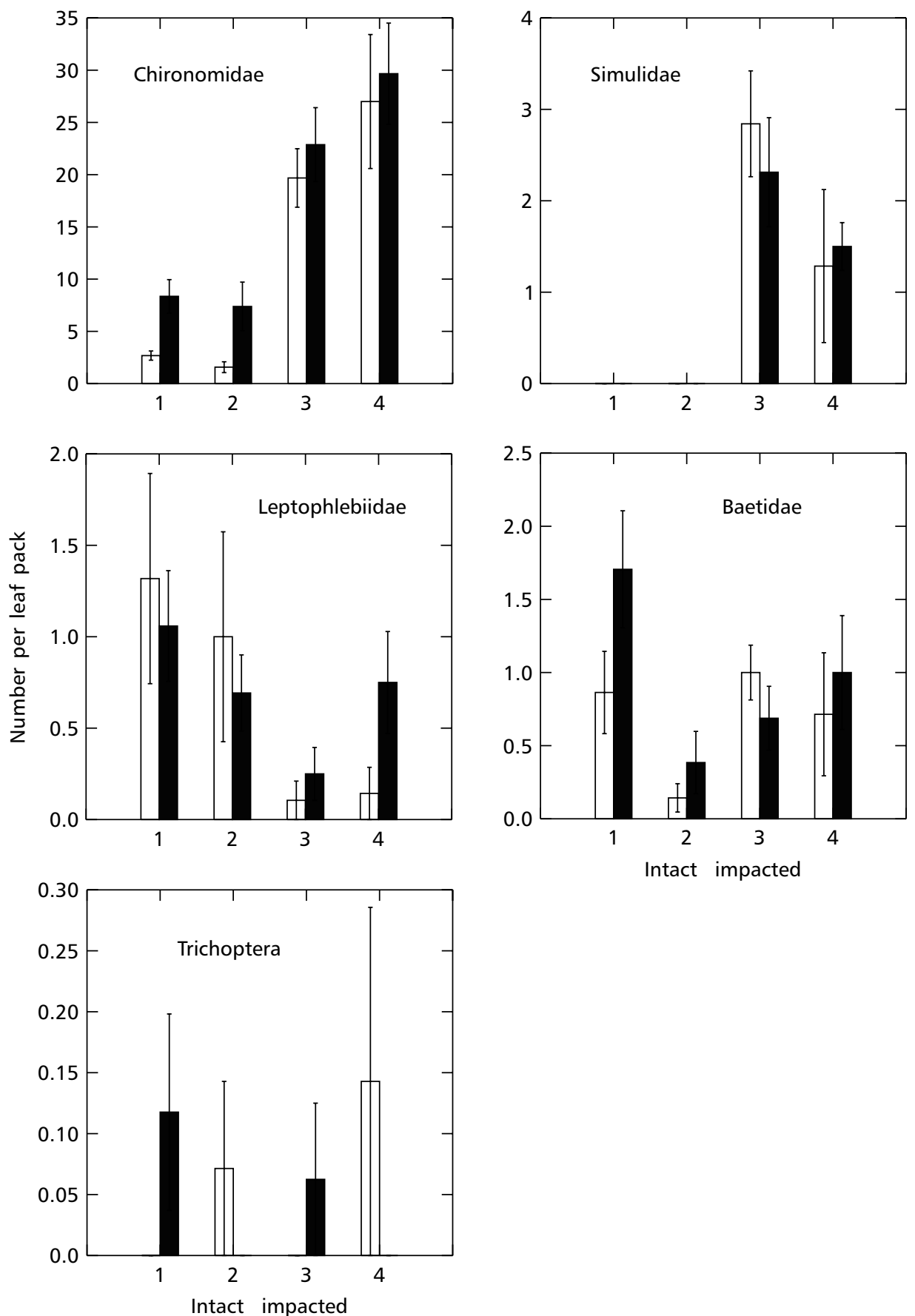

Fig. 3 - Abundance of selected taxa in leaf packs in impacted and intact streams. Abundance is expressed as mean number of individuals per leaf pack. Open bars are means for leaf-species Myrcia, closed bars for Piper. Streams numbered 1 and 2 are "intact-1" and "intact-2"; 3 and 4 are "impacted-open" and "impacted-closed". Bars represent the standard error of the mean (for leaf species Myrcia: "intact-1", $\mathrm{n}=22$; "intact-2", $\mathrm{n}=14$; "impacted-open", n = 19; "impacted-closed", $\mathrm{n}=7$; leaf species Piper: "intact-1", $\mathrm{n}=17$; “intact-2", $\mathrm{n}=13$; “impacted-open", $\mathrm{n}=16$; "impacted-closed", $\mathrm{n}=12$ ). 


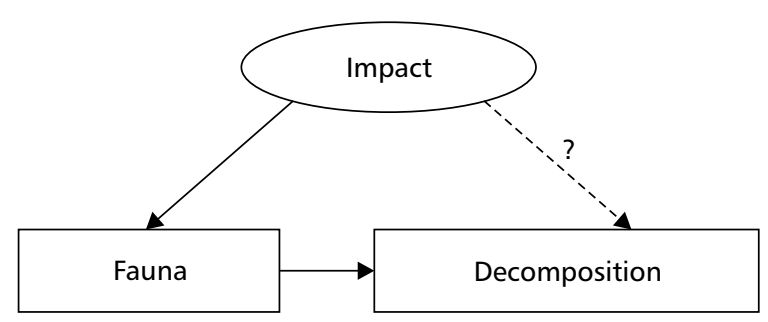

Fig. 4 - Hypothetical causal relationships between impact, fauna and decomposition. Impact may affect decomposition via its effect on the fauna, or directly as indicated by the dotted line.

Although the overall diversity of macroinvertebrates was not significantly different between the leaves in impacted and intact streams, the composition of the taxa was different, and we can ask whether a specific important component of the community was affected by impact. We did not separate the fauna into their functional groups, but we know that certain groups are important in leaf processing, principally by their action of shredding and scraping of the leaves. Such organisms may derive part of their nutrition from the fungi and other microbiota of the leaf surface. We have little data on the diets of Brazilian aquatic macroinvertebrates, but extrapolating from the literature we can suppose that some of the Ephemeroptera larvae of our study were scrapers of surface algae and detritus. The higher density of leptophlebiid Ephemeroptera on Myrcia in intact streams correlates with the faster leaf processing. On the other hand, Simulidae (larvae of black flies or "borrachudo") were extremely common on hard substrates and occurred on leaf packs in the impacted streams and were absent in the collections from the intact streams. Larval Simulidae filter fine organic particles from the water and probably do not take part in leaf processing.

The larger more mobile fauna differed markedly between the impacted and intact streams. The intact streams had relatively dense populations of omnivorous shrimp (Macrobrachium olfersi: Palaemonidae) and herbivorous/detritivorous shrimp (Potimirim glabra: Atyidae) but very low densities of fish and tadpoles. The impacted streams had no shrimp or fish, but abundant tadpoles (particularly the surface-feeding species Phasmohyla guttata). These species could have been active on the leaves without being sampled when the leaves were collected. Our continuing experiments aim to differentiate the effects of fauna of different sizes (Moulton, 2001).

The microbial component of the leaf processing is probably the most important, at least in quantitative terms. Generally, microbes (particularly fungi) account for a large percentage of aquatic organic matter decomposition (Gessner \& Chauvet, 1994). We quantified this in exclusion experiments at Ilha Grande and concluded that approximately $15 \%$ of the leaf processing could be attributed to the action of the macroinvertebrates (Magalhães, 1998). We plan to investigate the role of microbes in our continuing studies of the impacted streams, using experimental exclusion of macroinvertebrates and direct quantification of the microbes.

\section{Lessons for biomonitoring and understanding stream processes}

Most biomonitoring uses the responses of organisms to indicate environmental impact. Macroinvertebrates are often used in this context (Moulton, 1998; Rosenberg \& Resh, 1993). The tacit implication is that the organisms are indicating something important about the ecosystem. We believe that the actual ecosystem processes ("ecosystem functioning") can be monitored directly, and that leaf processing rate can be measured simply and inexpensively (Moulton, 2001). Our preliminary results indicate that perhaps this ecosystem parameter is not as insensitive to environmental impact as the orthodoxy suggests.

The understanding of biodiversity and ecosystem functioning is important for conservation and recovery of streams (Moulton, 1999). Although it appears that all components of biodiversity are not essential for ecosystem functioning, as in the redundant rivets analogy of Ehrlich \& Ehrlich 
(1981), we cannot predict which are the most important or how many we can afford to lose before ecosystem functions are compromised. In the present case, it appears that two urban forest streams of Rio de Janeiro have been substantially modified from their original state, as judged by comparison of intact streams in a similar geographical situation.

Acknowledgments - The experiments were part of a Masters program in Biology at Instituto de Biologia Roberto Alcântara Gomes, UERJ. Sandra Magalhães received a post-graduate scholarship from CNPq; T. P. Moulton received a productivity scholarship (APQ) from CNPq (projeto integrado 520549/ 97-0). We thank the Centro de Estudos Ambientais e Desenvolvimento Sustentado at Ilha Grande and the director and staff of Parque Estadual da Pedra Branca for logistic support, and our many colleagues for help in the field and laboratory.

\section{REFERENCES}

BÄRLOCHER, F., 1997, Pitfalls of traditional techniques when studying decomposition of vascular plant remains in aquatic habitats. Limnetica, 13: 1-11.

BENFIELD, E. F., 1996, Leaf breakdown in stream ecosystems, pp. 579-590. In: F. R. Hauer \& G. A. Lamberti (eds.), Methods in stream ecology. Academic Press, San Diego.

EHRLICH, P. R. \& EHRLICH, A. H., 1981, Extinction: the causes and consequences of the disappearance of species. Random House, NY.

GESSNER, M. O., 1991, Differences in processing dynamics of fresh and dried leaf litter in a stream ecosystem. Freshwater Biology, 26: 387-398.

GESSNER, M. O. \& CHAUVET, E., 1994, Importance of stream microfungi in controlling breakdown rates of leaf litter. Ecology, 75: 1807-1817.

HECTOR, A., SCHMID, B., BEIERKUHNLEIN, C., CALDEIRA, M. C., DIEMER, M., DIMITRAKOPOULOS, P. G., FINN, J., FREITAS, H., GILLER, P. S., GOOD, J., HARRIS, R., HÖGBER, G. P., HUSSDANELL, K., JOSHI, J., JUMPPONEN, A., KÖRNER, C., LEADLEY, P. W., LOREAU, M., MINNS, A., MULDER, C. P. H., O'DONOVAN, G., OTWAY, S. J., PEREIRA, J. S., PRINZ, A., READ, D. J., SCHERER-LORENZEN, M., SCHULZE, E-D., SIAMANTZIOURAS, A-S., SPEHN, E., TERRY, A. C., TROUMBIS, A. Y., WOODWARD, F. I., YACHI, S. \& LAWTON, J. H., 1999, Plant diversity and productivity in European grasslands. Science, 286: 1123-1127.
MAGALHÃES, S. A. P., 1998, Decomposição e fauna associada em folhas de Myrcia rostrata De Candolle e Piper divaricatum Meyer, em dois rios da Ilha Grande, RJ. MSc Thesis, Pós-Graduação em Biologia, Universidade do Estado do Rio de Janeiro, RJ.

MALTCHIK, L. \& PEDRO, F., 2000, Biodiversity influences community stability? Results of semiarid shallow lakes. Ciência e Cultura, 52: 127-130.

MOULTON, T. P., 1998, Saúde e integridade do ecossistema e o papel dos insetos aquáticos, pp. 123-140. In: J. L. Nessimian \& A. L. Carvalho (eds.), Ecologia de insetos aquáticos. Oecologia Brasiliensis, vol. V, PPGE-UFRJ, Rio de Janeiro.

MOULTON, T. P., 1999, Biodiversity and ecosystem functioning in conservation of rivers and streams. Aquatic Conservation: Marine and Freshwater Ecosystems, 9: 573-578.

MOULTON, T. P., 2001, Beyond monitoring - the understanding of biodiversity and ecosystem functioning in streams of the Atlantic Rainforest, Brazil, pp. 441-445. Proceedings of the Third Australian Stream Management Conference, Brisbane, 27-29 August, 2001, CRC for Catchment Hydrology, Melbourne, Australia.

PRINGLE, C. M., 1997, Exploring how disturbance is transmitted upstream: going against the flow. Journal of the North American Benthological Society, 16: 425-438.

REICE, S. R. \& WOHLENBERG, M., 1993, Monitoring freshwater benthic macroinvertebrates and benthic processes: measures for assessment of ecosystem health, pp. 287-305. In: D. M. Rosenberg \& V. H. Resh (eds.), Freshwater biomonitoring and benthic macroinvertebrates. Chapman \& Hall, NY.

ROSENBERG, D. M. \& RESH, V. H., 1993, Freshwater biomonitoring and benthic macroinvertebrates. Chapman \& Hall, NY.

TILMAN, D. \& DOWNING, A., 1994, Biodiversity and stability in grasslands. Nature, 367: 363-365. 